\title{
Applying appropriate models to predict bankruptcy for Vietnamese listed construction companies
}

\author{
Thi Hong Thuy Nguyen ${ }^{a^{*}}$, Lan Phuong To ${ }^{a}$, Kien Phan Trung ${ }^{b}$ and Thi Thuy Hang Dangb
}

${ }^{\mathrm{a}} V N U$ University of Economics and Business, Vietnam

${ }^{b}$ National Economics University, Vietnam

\begin{tabular}{l}
\hline C H R O N I C L E \\
\hline Article history: \\
Received July 10, 2021 \\
Received in revised format July \\
252021 \\
Accepted August 152021 \\
Available online \\
August 15 2021 \\
\hline Keywords: \\
Bankruptcy \\
Z-Score \\
Financial distress \\
Bankruptcy
\end{tabular}

\section{A B S T R A C T}

This study focuses on assessing the suitability and condition of various bankruptcy risk models applied to construction companies listed on the Vietnam Stock Market. In this study, the panel data were collected from the disclosed financial statements of the companies from 2012 to 2017. Through the assessment, bankruptcy risks are predicted for the companies that are experiencing initial signals such as delisting, compulsory supervision. In the next step, interviews were conducted to justify which of the following factors may indicate the companies at the risk of being bankrupted: asset management, capital structure, business size, and/or state management.

\section{Introduction}

Started in 1986, the "Doi moi" reform in Vietnam has remarkably achieved success in the development of the Vietnam economy. Construction companies have also been growing and keeping a significant role in the economy. Accordingly, the output value of these companies added to the economy accounted for VND 73,702 billion (GSO, 2018). Keeping the capitalized value of VND 81,331 billion, they kept the growth rate at $8.70 \%$ and stood at the third among the highest contributions of other industries to the GDP in 2017 and its preliminary to VND 93,110 in 2018 (GSO, 2018). As a cornerstone, they contribute to the achievements of other industries in Vietnam. The industry is estimated to soar due to the stable high growth rate of GDP in 2018. The rate even reached 7.03\% in 2018 (GSO, 2018) which exceeded the target of $6.7 \%$.

However, the fact that Vietnam's economy is integrating into the global business has brought opportunities as well as threats to local businesses, including local construction companies. These companies are now in a fierce competition market where foreign construction companies having financial and technology powers have already joined in. The problems are rising in many local construction companies due to the fragmented nature of the construction, a few entry barriers, and relevant high uncertainties (Kale \& Arditi, 1999; Kangari, 1988). Additionally, the reform of the economy may also have effects on construction companies. The operations of these companies are susceptible to influences that are resulting in changing the macroeconomic policies, the price of producing inputs or expenses in general, and their revenue. Consequently, these contracting companies faced more difficulties than usual, and eventually, those incapable or inexperienced companies may have troubles in their solvency (Schaufelberger, 2003) and even faced financial distress.

* Corresponding author

E-mail address: nththuy@vnu.edu.vn (T. H. T. Nguyen)

(C) 2022 Growing Science Ltd. All rights reserved.

doi: 10.5267/j.ac.2021.8.001 
Although Vietnamese construction companies have increasingly developed, they still face a few issues, especially with project funding and technology. Since it takes a change for foreign contractors who have financial power and high-tech solutions to join in significant projects and to expand to other projects, they compete with these local construction companies. Russell and Zhai (1996) confirmed that it is not unusual to spread out the financial healthiness of given contractors before they are invited to be a partner implementing a project. It differs from which contractor is more susceptible to being out of business that may not be easy as a company having cognitive performance may suddenly bankrupt due to financial insolvency (Davidson \& Maguire, 2003). An insolvent employed contractor is deeply rooted as another contractor has to be brought in to finish the construction project that could have been in time and overrun relevant cost (Mason \& Harris, 1979). The recognition of the possible financial distress impacted on a construction project is desirable to forecast the foreseeable failure of a contractor concerning at a point of time when there has been a lack of understanding of local construction companies in a particular country like Vietnam and economic austerities related.

Prior studies showed that most of the financial failures in the construction discipline were found to emphasize the project level for prequalification purposes (e.g. Morris \& Hough, 1987; Hall, 1982). Meanwhile, some other studies addressed the issue relating to the legal and organizational theory perspectives (Kele \& Arditi, 1999; Russell \& Casey, 1992). Early, many studies dedicated to the company level (e.g. Abidali \& Harris, 1995; Mason \& Harris, 1979) based on Altman's studies, emphasized building models or indicators that help users to identify financial distress and financial position of construction companies (Hanzaee, 2010). Nonetheless, the application of the Z-score model for the foreseeability of insolvency within the construction industry, especially in Vietnam, is generally in doubt.

This study aims at developing the warning model of solvent prediction which can help users to address the financial performance of construction companies listed in the Vietnam Stock Exchange (VSE). Based on the original model of Zscore, it will be adjusted in the context of Vietnamese construction companies listed in VSE. The model, then, is examined to the data set and the modeling techniques used for this study. Consequently, a description of the resulting model for early warning of financial chaos and the disclosure of the results of the model validations will be chosen. Finally, the implications of findings suggested in the study concerning the application of the Z-score model for Vietnam construction companies listed in VSE will be proposed.

\section{Methods for predicting the insolvency of a company}

Bankruptcy is a state in which a business falls into difficulties or suffers losses in its business operations after applying the necessary financial measures while is still unable to pay due debts. There are many reasons for corporate bankruptcy, both subjectively and objectively, mainly because of the fluctuation of the economy. A bankrupt business can have a dramatic effect on another business or even on the economy.

Several studies around the world have mentioned corporate bankruptcy, especially during times of economic crisis. In this article, we will focus on the measurement model and determine the threshold of bankruptcy for listed companies in the Vietnam Stock Market - applied to the construction industry.

\subsection{Financial indicator analysis}

In the world, many studies have pointed out how to identify the threshold of corporate bankruptcy. Since Beaver's prediction theory and the establishment of a corporate bankruptcy threshold in 1966, (Beaver, 1966), it had a significant impact on the entire world economy and has begun a series of following forecasting bankruptcy models. Many application models with explanatory variables and statistical methods are comprehensively used to estimate the threshold. In most models, the dependent variable usually receives two values of " 1 " if the company is in danger of bankruptcy, or " 0 " if the company does not have bankruptcy risk. Independent numbers are often the indicators that are calculated from financial statements and are usually related to profitability, liquidity, and corporate debt, the volatility of the market value of the rate of return of the stock, and the growth of income over the years.

However, empirical research models based on financial indicators show superiority. Altman and Edward (1968) firstly applied the multiple discriminant analysis (MDA) model to the analysis of factors influencing financial risk.

\subsection{Z-Score models}

Altman's Z-Score model is a composite measurement of financial risk, allowing the identification of corporate financial risk by distinguishing between the "insolvent" and the "non-insolvent". Many empirical studies have used the Z-score model because of its superiority, which makes it easy to calculate, compare and identify financial risks (Zhao \& Wang, 2006; Wu \& Zhou, 2006; Porporato, 2008; Lana IVIČIĆ \& Saša CEROVAC, 2009; Ann-Katrin Napp, 2011). However, the Z-score model also has certain limitations: It only distinguishes companies that are in groups of the "insolvent" and the "noninsolvent". Insolvency falls into several categories, from non-payment or late payment of loans or interest. Therefore, it is necessary to classify groups of companies responding to different levels of bankruptcy. Similarly, variables (Xj) are not invariant and may not be completely independent, especially when market and business conditions change frequently. The Z-score model also does not take into account some essential but quantifiable factors, such as corporate governance, industry prospects, and branding. The key research points may be categorized as follows: 


\begin{tabular}{|c|c|c|}
\hline Authors & Research methods and results & Notification \\
\hline $\begin{array}{l}\text { Collins and } \\
\text { Green }(2982)\end{array}$ & $\begin{array}{l}\text { It used three statistical models to predict bankruptcy. The authors analyzed the } \\
\text { multifactorial, linear, and regression models. They also made Comparative analysis } \\
\text { and comparison of models to evaluate the effectiveness and statistical properties, } \\
\text { consideration of factors influencing the selection of models following the theory of } \\
\text { financial crisis. }\end{array}$ & $\begin{array}{l}\text { The model used in their study is the most } \\
\text { appropriate model to help predict bankruptcy of } \\
\text { business better for the business when defining } \\
\text { the threshold rather than wanting to change the } \\
\text { financial ratios of the same magnitude in the } \\
\text { condition of the probability of failure in } \\
\text { business, which leads to bankruptcy. }\end{array}$ \\
\hline $\begin{array}{l}\text { Wu et al., } \\
2010\end{array}$ & $\begin{array}{l}\text { Make a comparison of five commonly used models to predict bankruptcy using } \\
\text { different independent variables (accounting information, market data, company } \\
\text { data, the probability from quantitative models, and a variety of econometric } \\
\text { indicators.) } \\
\text { Critical accounting information relates to profit, liquidity, and debt leverage. } \\
\text { Notably, the probability of bankruptcy increases as EBIT is reduced over total } \\
\text { assets, a sharp decline in earnings, a low working capital per capita, or the indicator } \\
\text { of debt to equity is high. }\end{array}$ & $\begin{array}{l}\text { There should be sufficient information on } \\
\text { accounting information, market data, and the } \\
\text { status of the business to apply the model. }\end{array}$ \\
\hline Ohlson, 1980 & $\begin{array}{l}\text { The model used is a logistics model based on accounting indicators. However, the } \\
\text { model used limited assumptions over Altman's model by the multiple-discriminant } \\
\text { analysis approach. This model is based on seven fundamental characteristics of the } \\
\text { business: Debt ratio, Debt leverage, Short-term asset turnover rate, Asset turnover } \\
\text { ratio, Earnings / Revenue ratio, Productivity, and Return on Equity. }\end{array}$ & $\begin{array}{l}\text { This model worked well in the } 1970 \text { s but has } \\
\text { been ineffective in recent years. }\end{array}$ \\
\hline $\begin{array}{l}\text { Korol and } \\
\text { Korodl, } 2011\end{array}$ & $\begin{array}{l}\text { Use fuzzy logic to predict the bankruptcy of a business for one, two to three years. } \\
\text { Use financial statements of } 132 \text { joint-stock companies ( } 25 \text { bankrupt companies and } \\
107 \text { non-bankrupt companies). The research also presented the verification and } \\
\text { effectiveness of fuzzy logic models in the prediction of corporate bankruptcy. }\end{array}$ & $\begin{array}{l}\text { Fuzzy logic models are proposed to use as input } \\
\text { financial ratios, along with their continuous } \\
\text { fluctuations. }\end{array}$ \\
\hline $\begin{array}{l}\text { Vickers } \\
(2006)\end{array}$ & $\begin{array}{l}\text { Set up a bankruptcy calculator based on Altman's Z-Score model with a } \\
\text { discriminating index of } 0.862 \text {. }\end{array}$ & $\begin{array}{l}\text { The Vickers has abandoned the market value of } \\
\text { the equity on the book value of debt, changing } \\
\text { the Retained Earnings to total assets by the pre- } \\
\text { tax profit on total debt, reflecting the } \\
\text { profitability of the loan (suitable for listed } \\
\text { construction companies in Vietnam, } \\
\text { mobilizing up to } 68 \% \text { of the total debt).. }\end{array}$ \\
\hline
\end{tabular}

A recent study presented a system based on the fuzzy logic model proposed to be used as input financial ratios to predict the insolvency of a firm, along with their constant fluctuations (Korol \& Korodl, 2011). To design and implement the model, the authors used the financial statements of 132 joint-stock companies ( 25 bankruptcies and 107 not bankrupt). The paper also presents the verification and effectiveness of fuzzy logic models in the prediction of corporate bankruptcy. Based on the models of prediction created by Warren Miller using financial data provided by Morningstar, the study tested the application possibilities of the two models. The most used is the Z-score model based on Altman's financial index and the "distance to default" model, which is currently used by Morningstar to rank the financial status of publicly listed companies on the market. In this study, the author has examined the ability of each model ranked to distinguish among the most likely bankrupt companies and compared to the lowest possible bankrupt firms that used measures of accuracy ratio. It also verified the dominance of each model in predicting bankruptcy when they jointly used the bankruptcy rate of well-ranked companies and the average rating before bankruptcy. The degradation of the ranking results of each model over time, when measured, is the same as the cumulative percentage change in rank order; the stability of results of each model as measured by weighted average drift distance (WADD). According to the author, the Z-score model is not intended for non-manufacturing companies (Altman \& Hotchkiss, 2006). However, in practice, the authors find that it is often used to assess the financial health of all both manufacturing and non-manufacturing companies. For Morningstar research, the Z-score model is more appropriate when considering non-manufacturing companies in situations they assess. As for distance to default, it can predict bankruptcy and ranking well in all corporate situations. This model yields more stable bankruptcies, but in the ratings, it produces fewer stable ratings than the Z-score model. Research by Pompe and Bilderbeek (2005) showed that most of the financial indicators could predict the bankruptcy of the business. The cash flow / total debt ratio gives accurate results for both old and new companies, and for large scale companies in the (Beaver \& William H, 1966). The issue of collecting information is more important as the author asserts that the more data collected to analyze the threshold for bankruptcy, the more reliable the predicted outcome3. In the study, the impact assessment of the variable selection approach on the accuracy of bankruptcy models by (Philippe du Jardin, 2004).

Thus, in the study of the world over the past four decades, the authors have focused on two main objectives: (i) Evaluate the conditions at which the models operate; (ii) Focus on explanatory variables that can be used to design the model. In all the parameters that influence the accuracy of the model, there is "one less often discussed" element: the effect of the variable selection method on the model. (Jardin \& Philippe, 2014) Offered a paper to assess the accuracy of the model of bankruptcy associated with different classification techniques and variable selection methods. The study emphasized the inability to design a search strategy without regard to the characteristics of the modeling technique and the fit between the modeling technique and the variable selection method. In the search for variables based on different standards, the research results selected three tables with three groups of seven variables. The selected group needs to account for more than $70 \%$ of the final model result. Depending on the frequency of choice, variable names may fall into the categories. 
The combination of choice for growth and asset issue of a company is a critical determinant of the company's optimal strategy. While a reasonably long list of variables can be used in bankruptcy prediction models, measurement of investment opportunities has not been considered (Campbell et al., 2008; Hsieh et al., 2011), who have researched investment opportunities and forecasts for corporate bankruptcy. The authors pointed out that the shareholders of the company having significant investment opportunities may be willing to wait even longer before their insolvency concerning their shareholders becomes insolvent in comparison with another company without such valuable investment opportunities. More importantly, through the recent data on the bankruptcies of companies, research has shown that measures of investment opportunities are strictly related to the probability of bankruptcy. Using these measures in conjunction with the bankruptcy predictions model will help to improve the company's ability to predict bankruptcy when considering new investment opportunities.

In summary, there are many financial variables given to determine the threshold of corporate bankruptcy. Depending on the application conditions for each company, the model of company bankruptcy will be based on the appropriate financial variables.

In Vietnam, during the current financial crisis, identifying corporate bankruptcy thresholds and quantitative construction models are essential. Therefore, the research aims to build the prediction models and set the threshold of bankruptcy that can be applied to Vietnamese companies.

In Vietnam, by the end of 2010, Tan Viet Securities Company had calculated and provided the index Z of listed shareholding companies to investors by mainstream channels. However, Tan Viet Securities Company used Altman's original Z-Scored model built on data from 66 US companies from 1946 to 1965, which may be inaccurate due to differences in timing, economic conditions, and the legal environment between the two countries. To overcome this disadvantage, Dinh The Hien in his research adjusted the parameters of the Z' equation in line with Vietnam's economic conditions, of the asset investment structure over the total asset coefficient.

The author has explained the scientific basis and provided evidence in two cases, namely Tuong An Oil Joint Stock Company (TAC) and Phuong Nam Cultural Products Company (PNC). However, the result did not represent all Vietnamese companies.

In Khong Thanh Hoa (2008), using the 2007 data set of 230 listed companies listed on the Ho Chi Minh and Hanoi Stock Exchange, repeat the analysis like Altman to estimate the Z-Score model. For the discriminative value of 1.0689, the proposed Z-score of Vietnam is determined by the equation:

$Z_{\text {Vietnam }}=0.204 \mathrm{X} 1+1.386 \mathrm{X} 2+2.211 \mathrm{X} 3+0.009 \mathrm{X} 4+0.488 \times 5$

The reliability of the model is $70 \%$, acknowledging the great efforts of the author to build the first model $\mathrm{Z}$ for the stock market in Vietnam. However, as the debt and bond market of Vietnam has not developed yet, the author did not accurately classify the bankruptcy and non-bankruptcy companies as they did at the beginning. The distress will receive a value of 1 (equivalent to potential financial distress) if the business is listed on the Ho Chi Minh City Stock Exchange or has a negative business result (loss) or profit after tax of less than $10 \%$ of the plan. Distress will receive the value of 0 (not inactive financial status) when not falling into the above cases. This scale is not suitable for the risk of insolvency of companies.

Dao Thi Thanh Binh (2011) conducted the same research with a sample of 60 listed companies in the manufacturing sector, criteria for "lowest after-tax profit in 4 quarters - up to the second quarter of 2010 "as the basis for distinguishing the company "Bad" or "Good". At the same time, the variables "the revenue/total assets" were replaced by the variable "market capitalization/book value"; added three new variables: "total debt / total assets"; "net profit/revenue," and "net profit / fixed assets". The reliability of the study was $86 \%$, obtaining the equation of the form:

$Z_{\text {Vietnam }}=1.268 \mathrm{X} 1-1.179 \mathrm{X} 2-0.56 \mathrm{X} 3+0.023 \mathrm{X} 4+0.185 \mathrm{X} 5-0.009 \mathrm{X} 6+0.411 \mathrm{X} 7+6.641 \mathrm{X} 8-1.888$

Distinct values are defined as 0.575 and 0.975 . After calculating the Z-scores for 46 companies in the group, compared to Standard \& Poor's credit rating results, there was a clear difference between the "top" and "bottom" groups. However, the research applicability is low due to their small sample size and unreasonable business rationale, affecting the suitability of results.

\subsection{Predictability of Z-Score model for Vietnamese construction companies listed in Vietnam Stock Exchange}

Application of model Z scores for listed construction joint-stock companies in Vietnam will face difficulties in determining some variables such as the market value of equity on the book value of debt. Therefore, the authors decided to abandon the market value of equity on the book value of debt. That led to another application of the Z-score of Vickers, a company that provides tools to support economic analysis and financial reputation in the world. It was Founded in 1960, with the help of consultants, financial analysts, mathematicians, statisticians, Microsoft Office professionals, and successful business owners through their website. The Vickers 'Bankruptcy Calculator is based on Altman's Z' model with a discriminating index of 0.862 . However, The Vickers has abandoned the market value of equity on the book value of debt (this is in line with Vietnam's market - as pointed out by Dinh The Hien and Khong Thanh Hoa), change retained earnings on total assets 
by earnings before tax on total debt, reflect the profitability of the loan (suitable for listed construction companies in Vietnam, mobilize up to $68 \%$ debt in total capital).

$$
Z_{\text {jaxworks }}=1.03 \beta_{1}+3.07 \beta_{2}+0.66 \beta_{3}+0.4 \beta_{4}
$$

$\beta 1$ : Net working capital / Total assets

$\beta 2$ : Profit before tax and interest / Total assets

33: Profit before tax / Debt

34: Revenue / Total Assets

The Z-score is measured in this research by using the data set of 180 annual financial statements of 30 listed construction companies from 2012 to 2017.

\section{The Z-score model application for the construction companies listed in the Vietnam Stock Exchange}

\subsection{Applying $Z_{\text {jaxworks }}$ model to measure the risk of bankruptcy of construction companies listed in Vietnam}

First, the research team preliminary statistics the number of joint-stock construction companies listed in the short-term risk of bankruptcy each year, applying the $\boldsymbol{Z}_{\text {jaxworks }}$ model, the results are as follows:

Table 2

Value of $Z$ index over the years of listed construction companies from 2012 to 2017 - $Z_{\text {jaxworks }}$ model

\begin{tabular}{|c|c|c|c|c|c|c|}
\hline Securities Symbol & 2012 & 2013 & 2014 & 2015 & 2016 & 2017 \\
\hline $\mathrm{BCE}$ & 1.1459 & 0.9682 & 0.9572 & 0.8988 & 0.5399 & 0.5359 \\
\hline C47 & 0.5794 & 0.4524 & 0.2852 & 0.4624 & 0.2927 & 0.4144 \\
\hline CDC & 0.5716 & 0.5355 & 0.4355 & 0.4241 & 0.5576 & 0.6439 \\
\hline CIG & 0.7191 & 0.7398 & 0.6517 & 0.7057 & 0.4319 & 0.2021 \\
\hline CII & 0.2547 & 0.1990 & 0.0295 & $(0.0300)$ & 0.2549 & 0.1416 \\
\hline CLG & 0.1755 & 0.3616 & 0.3591 & 0.2603 & $(0.0419)$ & 0.2229 \\
\hline CTD & 1.2130 & 1.2415 & 1.0346 & 1.0926 & 1.0655 & 1.0701 \\
\hline D2D & 0.3799 & 0.2414 & 0.6557 & 0.5388 & 0.6015 & 0.4835 \\
\hline FCN & 0.6105 & 0.6397 & 0.5396 & 0.6034 & 0.4948 & 0.5776 \\
\hline HAS & 0.6748 & 0.6740 & 0.9138 & 0.7154 & 0.6331 & 0.7222 \\
\hline НBC & 0.5036 & 0.4388 & 0.4252 & 0.3626 & 0.3483 & 0.3368 \\
\hline HTI & 0.2379 & 0.3110 & 0.1740 & 0.0716 & 0.1004 & 0.1790 \\
\hline HU1 & 0.5330 & 0.5754 & 0.4072 & 0.4320 & 0.6154 & 0.6292 \\
\hline HU3 & 0.4467 & 0.7764 & 0.4753 & 0.5342 & 0.7668 & 0.5056 \\
\hline L10 & 0.3444 & 0.4154 & 0.4724 & 0.5781 & 0.7185 & 0.5058 \\
\hline LCG & 0.6731 & 0.4968 & 0.2692 & $(0.0228)$ & 0.4850 & 0.3803 \\
\hline LDG & 0.3983 & 0.3317 & 0.5440 & 0.4792 & 0.4641 & 0.7495 \\
\hline MCG & 0.5511 & 0.4469 & 0.3981 & 0.1910 & 0.3033 & 0.3781 \\
\hline MDG & 0.5062 & 0.2188 & 0.2029 & 0.2017 & $(0.0310)$ & 0.2197 \\
\hline PTC & 0.4678 & 0.4654 & 0.1632 & 0.4577 & 0.6461 & 0.4400 \\
\hline PXI & 0.8817 & 0.5249 & 0.2772 & 0.3008 & 0.3159 & 0.4281 \\
\hline PXS & 0.2203 & 0.2989 & 0.4798 & 0.2794 & 0.5427 & 0.3642 \\
\hline PXT & 0.8181 & 0.6640 & 0.4819 & 0.3086 & $(0.3912)$ & 0.3763 \\
\hline REE & 0.4220 & 0.6371 & 0.5916 & 0.7127 & 0.6856 & 0.6098 \\
\hline SC5 & 0.5734 & 0.4824 & 0.5439 & 0.3260 & 0.4185 & 0.4754 \\
\hline SRF & 0.8349 & 0.7562 & 0.7647 & 0.7888 & 0.6917 & 0.7673 \\
\hline THG & 0.7040 & 0.6337 & 0.7305 & 0.6898 & 0.7188 & 0.7133 \\
\hline UDC & 0.2186 & 0.1786 & 0.1479 & 0.2470 & 0.2661 & 0.1872 \\
\hline VNE & 0.4839 & 0.3894 & 0.2812 & 0.1360 & 0.5525 & 0.3686 \\
\hline VSI & 0.3005 & 0.2940 & 0.1884 & 0.1530 & 0.2679 & 0.2408 \\
\hline
\end{tabular}

Source: Authors' calculations

The figures in the table above show the possibilities of company insolvency. Some of these companies have been placed under designated securities in the following years. Investment and trading of real estate Joint-stock company (ITC) were designated in 2018 because profit after tax of shareholders of the parent company for the first 06 months of 2018 is positive and net profit undistributed as of Jun. 30, 2018, is positive. At the same time, the company has used the amount of VND225,431,309,776 from capital surplus to handle losses on tax profit undistributed. Consequently, the profit after tax undistributed fact of ITC on Jun. 30, 2016, is harmful. The other case is Petroleum Pipeline \& Tank Construction Joint Stock Company (PXT): Profit after tax for the first 06 months of 2018 is favorable and undistributed profit tax until Jun. 30,2018 , is negative.

Although the number of business ventures is not much, in the period 2012-2017, more than $90 \%$ of the joint-stock listed companies in Vietnam were in danger of bankruptcy in the short term. This problem, once again, confirms that the solvency of debt is very different from the profit achieved after a business period, especially in a particular business sector such as construction. Besides, the average $Z$ value of the whole study tended to decrease significantly in 2016 , reflecting the severity of the situation. When measuring the risk of bankruptcy of the listed construction companies from 2012 to 2017 by the 
model of The Vickers company, the calculation could avoid assuming data on retained earnings, market capitals that distorts results. Therefore, in a situation where there is no suitable bankruptcy risk measurement model in Vietnam (as analyzed above), this model is appropriate.

Table 3

The average Z-score of listed construction companies from 2012 to 2017 - using the $\boldsymbol{Z}_{\text {jaxworks }}$ model

\begin{tabular}{|c|c|c|c|c|c|}
\hline \multirow{2}{*}{ Year } & \multicolumn{2}{|c|}{ Companies have $Z>\mathbf{~} \mathbf{0 , 8 6 2}$} & \multicolumn{2}{|c|}{ Companies have $\mathrm{Z}<0,862$} & \multirow{2}{*}{ Average $\mathbf{Z}$} \\
\hline & Number & Proportion & Number & Proportion & \\
\hline 2012 & 3 & $10.00 \%$ & 27 & $90.00 \%$ & 0.548 \\
\hline 2013 & 2 & $6.67 \%$ & 28 & $93.33 \%$ & 0.513 \\
\hline 2014 & 3 & $10.00 \%$ & 27 & $90.00 \%$ & 0.463 \\
\hline 2015 & 2 & $10.00 \%$ & 27 & $90.00 \%$ & 0.430 \\
\hline 2016 & 1 & $3.33 \%$ & 29 & $96.67 \%$ & 0.444 \\
\hline 2017 & 1 & $7.69 \%$ & 13 & $92.31 \%$ & 0.522 \\
\hline
\end{tabular}

Source: Authors' calculations

\subsection{Findings}

Due to the calculation above, we can classify into two groups: group 1 with total assets of less than 500 billion VND and group 2 with total assets of more than 500 billion VND. Using the 2014 dataset of 30 companies, with the help of SPSS software, the author calculated the $Z$ index of each business. Based on the 0.862 difference in liquidity $(Z<0.862)$ and group 2 , the risk of bankruptcy was very low $(Z>0.862)$.

Table 4

Descriptive statistics on Z-score in 2012-2017 of two groups of listed construction companies

\begin{tabular}{lcccccc}
\hline $\mathbf{Z}$ & Average & Number of Observations & Standard deviation & Lowest value & Highest value & $\%$ of total observations \\
\hline Group 1 & 0.530 & 12 & 0.247 & 0.073 & 1.21 & $40 \%$ \\
Group 2 & 0.476 & 18 & 0.241 & 0.029 & 1.25 & $60 \%$ \\
\hline Total & 0.503 & 30 & 0.243 & 0.021 & 1.25 & $100.0 \%$ \\
\hline
\end{tabular}

Source: Authors' calculations

Statistics show that: There are 12 companies in Group 1 with an average $\mathrm{Z}$ rating of 0.530 (lower than the reference level of 0.862 ) and 18 companies in the second group with a $\mathrm{Z}$ rating of 0.476 (low far more than the reference level of 0.862 ). There are only four companies as Binh Duong Construction and Transportation Joint Stock Company, Coteccons Construction Joint Stock Company, Haciscos Joint Stock Company, and Industrial and Civil Construction Joint Stock Company. Petroleum gas has $\mathrm{Z}$ greater than 0.862 . The remaining 26 listed construction companies (accounting for $86.67 \%$ ) fell into the state of $Z$ less than 0.862 . It shows a negative result for the construction industry, warning of the liquidity risk of companies operating in this area. It is a warning sign of the insolvency of most construction companies. Among the businesses at risk of bankruptcy listed above, the following companies are most at risk of bankruptcy, requiring useful and timely measures to improve the situation.

Table 5

List of listed construction joint stock companies in Vietnam at highest risk of bankruptcy in the period 2012 to 2016

\begin{tabular}{lcccccc}
\hline No & Securities Symbol & Z 2012 & Z 2013 & Z2014 & Z 2015 & Z 2016 \\
\hline 1 & C47 & 1.00 & 0.44 & 0.18 & 0.43 & -0.26 \\
2 & CII & 2.34 & -0.62 & -0.32 & -0.60 & 0.40 \\
3 & CLG & 1.67 & 0.20 & 0.28 & 0.29 & -0.62 \\
4 & HBC & 1.57 & 0.43 & -0.20 & 0.39 & 0.40 \\
5 & L10 & 0.84 & 0.40 & 0.43 & 0.52 & 0.77 \\
6 & LM8 & -0.68 & -0.32 & 0.15 & 0.00 & 0.42 \\
7 & SC5 & -0.19 & 0.50 & 0.27 & 0.01 & 0.01 \\
8 & UDC & 2.31 & 0.23 & 0.19 & 0.17 & 0.37 \\
9 & VSI & 0.06 & 0.34 & 0.40 & 0.17 & 0.39 \\
\hline
\end{tabular}

For the first time since 2012, the status of a listed construction company in Vietnam with a Z-value less than 0 , resulting from a business loss in using leverage at the high level of bankruptcy risk. Two companies belong to the Lilama group, which is not surprising in the context of the debt that has reached thousands of billion.

Table 6

List of five construction companies listed in Vietnam is at the highest risk of bankruptcy in 2017

\begin{tabular}{|c|c|c|c|c|}
\hline No & Securities Symbol & Z 2017 & D/A & ROA \\
\hline 1 & SC5 & -0.87 & $86.19 \%$ & $1.59 \%$ \\
\hline 2 & $\mathrm{HBC}$ & -0.51 & $85.26 \%$ & $1.14 \%$ \\
\hline 3 & CIG & -0.32 & $94.81 \%$ & $-9.00 \%$ \\
\hline 4 & TDC & 0.22 & $80.39 \%$ & $1.40 \%$ \\
\hline 5 & $\mathrm{BCE}$ & 0.27 & $83.74 \%$ & $1.48 \%$ \\
\hline
\end{tabular}

Source: Authors' calculations

Considering financial statements of listed construction companies in Vietnam with Z less than 0 (contrary), the reason is that the company maintains excessive use of financial leverage while doing business at a loss. 
T. H. T. Nguyen et al. / Accounting 8 (2022)

In the list above, there are four companies (80\%) with total assets of more than 500 billion VND with a debt ratio compared to total assets from $80,39 \%$ to $86,19 \%$. Particularly, COMA18 has some total assets of less than 500 billion VND and has a debt to total asset ratio of $94.81 \%$. Besides, COMA18 was placed under controlled securities. Considering the profitability coefficient on the total assets of these companies, the above-mentioned companies have low or even negative profit-earning assets. It means that each capital invested in businesses is being used ineffectively, making very little profit or loss, increasing the risk of losing funds to creditors, and the burden of financial liability to the owner.

\section{Assess the bankruptcy's risk of listed construction companies in Vietnam}

\subsection{The analysis}

By 2014, the risk of bankruptcy of the listed construction companies significantly increased implying that we should focus on analyzing and clarifying the cause. Therefore, using the data in 2017, the research team grouped in bankruptcy risk, asset size, Z-score, etc. to provide general information on the risk of bankruptcy of these companies. By calculating and comparing fundamental financial indicators, such as asset size, capital structure, business results, and asset management results between two groups of listed construction companies with and without the risk of bankruptcy, we detect significant differences, as the premise to verify the impact of each cause on the risk of bankruptcy. Before measuring the risk of bankruptcy of joint-stock construction companies listed in Vietnam, it is necessary to understand the preliminary financial situation of companies in the past.

Table 7

The number of joint-stock companies listed in Vietnam has suffered losses from 2012 to 2017

\begin{tabular}{|c|c|c|c|c|}
\hline \multirow[t]{2}{*}{ Year } & \multicolumn{2}{|c|}{ Companies with PAT $>0$} & \multicolumn{2}{|c|}{ Companies with PAT $<0$} \\
\hline & Number & Proportion & Number & Proportion \\
\hline 2012 & 30 & $100 \%$ & 0 & $0 \%$ \\
\hline 2013 & 30 & $100 \%$ & 0 & $0 \%$ \\
\hline 2014 & 27 & $90 \%$ & 3 & $10 \%$ \\
\hline 2015 & 27 & $90 \%$ & 3 & $10 \%$ \\
\hline 2016 & 26 & $86.67 \%$ & 4 & $13.33 \%$ \\
\hline 2017 & 12 & $92.31 \%$ & 1 & $7.69 \%$ \\
\hline
\end{tabular}

Source: Authors' calculations

Hence, with a summary analysis of some fundamental financial indicators, we found that the financial status of joint-stock construction companies listed in the two years 2013-2014 has significantly reduced compared to the period $2012-2013$ and 2016 - 2017, this result certainly increases the risk of bankruptcy listed companies.

Table 8

The average value of some indicators in construction sector listed companies in Vietnam from 2006 to 201

\begin{tabular}{|c|c|c|c|c|c|c|}
\hline Target & 2012 & 2013 & 2014 & 2015 & 2016 & 2017 \\
\hline Short term ratio (times) & 1.32 & 1.28 & 1.31 & 1.38 & 1.42 & 1.71 \\
\hline Quick ratio (times) & 0.76 & 0.76 & 0.81 & 0.87 & 0.28 & 0.15 \\
\hline Acid test ratio (times) & 0.15 & 0.11 & 0.15 & 0.18 & 0.91 & 0.11 \\
\hline Receivable turnover (days) & 187 & 373 & 654 & 94.26 & 83.08 & 89 \\
\hline Inventory turnover (days) & 101.4 & 48.35 & 74.23 & 66.48 & 50.71 & 114.50 \\
\hline ROA (times) & 0.41 & 0.33 & 0.22 & 0.11 & 0.002 & 0.12 \\
\hline Total ROA (\%) & 4.45 & 3.61 & 2.41 & 1.76 & 1.2 & 2.91 \\
\hline ROE $(\%)$ & 13.8 & 6.66 & -2.2 & 1.76 & 1.2 & 2.64 \\
\hline
\end{tabular}

Source: Authors' calculations

Thus, the survey of current listed construction joint-stock companies in Vietnam from 2012 to 2016 shows that the number of high-risk insolvent companies in the short-term accounts for 30\%. By 2017, the situation had improved to $16.67 \%$. It is a very positive signal for the Vietnamese construction industry. Although theoretically, the increase in scale gives businesses many advantages, thereby increasing economic efficiency, with the reality in the construction industry in Vietnam today, large companies have invested more than the value of assets, which is not increasing business results. However, the situation also incurred additional management costs, stagnation of capital, waste, and waste, so the profitability of a co-investment in assets is reduced. Combined with the weak ability to manage assets (including money, receivables, inventories, fixed assets), resulting in a prolonged return on investment also increases the risk of insolvent listed construction companies. Also, the debt ratio is too large in total capital, while the low efficiency of financial leverage has the opposite effect, threatening the liquidity of companies.

\subsection{The causes}

During in-depth interviews, managers of the 30 listed construction industry joint-stock companies were asked to assess the impact of each of the listed causes on the risk of bankruptcy of listing construction companies in Vietnam by ranking the causes. Asset management; Capital structure; Business managers' competence, state management mechanism; foreign competitors.

Twenty-three, in-depth interviews were conducted to find the reason for this case. Here the result of the interviews: 


\begin{tabular}{lc}
\hline Reasons & Percentage \\
\hline Poor asset management & $69.5 \%$ \\
Capital structure is not reasonable & $65.2 \%$ \\
Company size & $65.2 \%$ \\
Outside impact (state management mechanism) & $26.66 \%$ \\
Foreign competitor & $34.43 \%$ \\
\hline
\end{tabular}

The 23 respondents of the listed construction joint-stock company in Vietnam agree that the main reason for the increased risk of bankruptcy of these enterprises is the capital structure is not reasonable (most companies under controlled borrowed too much debt), the other thing that makes companies inefficient is poor asset management. At the same time, theoretically, according to the Zjaxworks calculation formula, the risk of bankruptcy of a business depends on the ability to exploit assets to generate business results, capital mobilization of the business, and the company size as well. This result is entirely consistent with the result of model Zjaxworks validation.

\section{Conclusion}

Based on the theoretical model as well as quantitative results, the authors found that subjective reasons leading to this situation were weak asset management capacity while there is financial leverage, capital structure, and company size. From the above research, to minimize the risk of bankruptcy, a business should be required to increase the number of $\mathrm{Z}$ norms by increasing the working capital, increasing retained earnings, increasing the market price of equity, or seeking to reduce debt. To adjust the capital structure to be consistent with the operating business, the company must review the structure of assets, investments; and at the same time, investigate liquidating inefficient assets or unused assets. These assets will not affect the company size. The situation of many construction companies shows that they use short-term debt financing for long-term investment. It helps to solve difficulties in the capital but also soon puts a business into financial difficulties when the debt has a short due date. Debt recovery will help to increase the amount of money in circulation, avoid appropriation of capital, and improve the financial position of the company. Therefore, it is necessary to collect enough information about customers, not continue to supply goods when the customer still owes an old backlog. For new clients and large businesses, there must be safeguards or precautions to take, and if they are unsafe or at high risk of debt default, they must refuse the business contract. The results of this study again warn listed construction companies and construction firms in Vietnam in general, should not consider the expansion of the scale by borrowing as a necessity, as an industry trait. The decision on investment and financing should be based on the ability to manage assets to generate profits for the business. In challenging business conditions, narrowing down, cutting costs, and focusing on core business is a viable option.

\section{Acknowledgement}

This research was partially supported by VNU University of Economics and Business. We thank our colleagues from VNU University of Economics and Business who provided insight and expertise that greatly assisted the paper.

\section{References}

Abidali, A. F., \& Harris, F. (1995). A methodology predicting failure in the construction industry. Construction Management and Economics, 13(3), 189 - 196.

Altman, E. I. (1968). Financial ratios, discriminant analysis and the prediction of corporate bankruptcy. The Journal of Finance, 23(4), 589-609.

Altman, E. I., \& Hotchkiss, E. (2006). Corporate financial distress and bankruptcy.

Ann-Katrin Napp. (2011). Financial risk management in SME: The use of financial analysis for identifying, analysing and monitoring internal financial risk. Master thesis, Aarhus School of Business, Aarhus University.

Beaver, W. H. (1966). Financial ratios as predictors of failure. Journal of Accounting Research, 4, 71-111.

Campbell, J. Y., Hilscher, J., \& Szilagyi, J. (2008). In search of distress risk. The Journal of Finance, 63(6), $2899-2939$.

Collins, R.A., \& Green, R.D. (1982). Statistical methods for bankruptcy forecasting. Journal of Economics and Business, 34(4), 349-354.

Davidson, R. A., \& Maguire, M. G. (2003). Ten most common causes of construction contractor failures. Journal of Construction Accounting and Taxation, 13(1), 35e 37.

du Jardin, P. (2012). The influence of variable selection methods on the accuracy of bankruptcy prediction models, 116, 2039.

Du Jardin, P. (2015). Bankruptcy prediction using terminal failure processes. European Journal of Operational Research, 242(1), 286-303.

GSO - General Statistic Office (2018), Statistical Yearbook of Vietnam, Statistical Publishing House.

Hall, G. (1982). Great planning disasters. Berkeley, CA: University of California

Hanzaee, A. H. (2010). Test of the generalizability of Altman's bankruptcy prediction model. In S. S. Mahmoud, J. Zhou, \& G. S. Tomar (Eds.), Proceedings: 2010 international conference on financial theory and engineering (ICFTE 2010), June 18e20, Dubai, United Arab Emirates (pp. 215e220). IEEE Press.

Hsieh, J., Lyandres, E., \& Zhdanov, A. (2011). A theory of merger-driven IPOs. Journal of Financial and Quantitative Analysis, 46(5), 1367-1405. 
Ivicic, L., \& Cerovac, S. (2009). Credit risk assessment of corporate sector in Croatia. Financial Theory and Practice, 33(4), 373-399.

Kale, S., \& Arditi, D. (1999). Age-dependent business failures in the US construction industry. Construction Management and Economics, 17(4), 493e503.

Kangari, R. (1988). Business failure in the construction industry. Journal of Construction Engineering and Management, ASCE, 114(2), 172e190.

Korol, T., \& Korodi, A. (2011). An evaluation of effectiveness of fuzzy logic model in predicting the business bankruptcy. Romanian Journal of Economic Forecasting, 3(1), 92-107.

Mason, R. J., \& Harris, F. C. (1979). Predicting company failure in the construction industry. Proceedings Institution of Civil Engineers, 66(Part 1), 301e307.

Morris, P. W. G., \& Hough, G. H. (1987). The anatomy of major projects: A study of the reality of project management. Chichester, UK: John Wiley \& Sons.

Ohlson, J. (1980). Financial ratios and the probabilistic prediction of bankruptcy. Journal of Accounting Research 18, 109131.

Pompe, P.P.M., \& Bilderbeek, J. (2005). The prediction of bankruptcy of small- and medium-sized industrial firms. Journal of Business Venturing 20(6), 847-868.

Russell, J. S., \& Casey, J. J., Jr. (1992). Design engineer/contractor failure from prior to contract award. Journal of Management in Engineering, ASCE, 8(3), $278 \mathrm{e} 297$.

Russell, J. S., \& Zhai, H. (1996). Predicting contractor failure using stochastic dynamics of economic and financial variables. Journal of Construction Engineering and Management, ASCE, 122(2), 183e191.

Schaufelberger, J. E. (2003). Causes of subcontractor business failure and strategies to prevent failure. In K. R. Molenaar, \& P. S. Chinowsky (Eds.), Proceedings: Construction research Congress 2003 e Winds of change: Integration and innovation of construction, March 19-21, Honolulu, Hawaii (pp. 593e599). ASCE Press.

Vickers, F. (2006). The Dynamic Small Business Managers. Lulu.com.

$\mathrm{Wu}, \mathrm{Y}$., Gaunt, C., \& Gray, S. (2010). A comparison of alternative bankruptcy prediction models. Journal of Contemporary Accounting \& Economics, 6(1), 34-45.

Wu, D., \& Zhou, J. (2006). Capital requirement and commercial bank's operation: An empirical analysis of large and medium commercial banks in China. Journal of Financial Research, 314(8), 144-153.

Zhao, X.J., \& Wang, S.B. (2006). Effect of new capital accord on lending of commercial banks. Studies of International Finance, 2, 36-42. 
(C) 2022 by the authors; licensee Growing Science, Canada. This is an open access article distributed under the terms and conditions of the Creative Commons Attribution (CC-BY) license (http://creativecommons.org/licenses/by/4.0/). 